\title{
Brain Injury Does Not Alter the Intrinsic Differentiation Potential of Adult Neuroblasts
}

\author{
Fang Liu, ${ }^{1 \star}$ Yan You, ${ }^{1 \star}$ Xiaosu Li, ${ }^{1}$ Tong Ma, ${ }^{1}$ Yanzhen Nie, ${ }^{1}$ Bin Wei, ${ }^{1}$ Tiejun Li, ${ }^{2}$ Huanbing Lin, ${ }^{3}$ and Zhengang Yang ${ }^{1}$ \\ ${ }^{1}$ Institutes of Brain Science and State Key Laboratory of Medical Neurobiology, Fudan University, 200032 Shanghai, People's Republic of China, \\ ${ }^{2}$ Department of Pharmacology, School of Pharmacy, Second Military Medical University, 200433 Shanghai, People's Republic of China, and ${ }^{3}$ Department of \\ Pharmacology, School of Pharmaceutical Sciences, Southern Medical University, 510515 Guangzhou, People's Republic of China
}

Neuroblasts produced by the neural stem cells of the adult subventricular zone (SVZ) migrate into damaged brain areas after stroke or other brain injuries, and previous data have suggested that they generate regionally appropriate new neurons. To classify the types of neurons produced subsequent to ischemic injury, we combined BrdU or virus labeling with multiple neuronal markers to characterize new cells at different times after the induction of stroke. We show that SVZ neuroblasts give rise almost exclusively to calretininexpressing cells in the damaged striatum, resulting in the accumulation of these cells during long term recovery after stroke. The vast majority of SVZ neuroblasts as well as newly born young and mature neurons in the damaged striatum constitutively express the transcription factor $\mathrm{Sp8}$, but do not express transcription factors characteristic of medium-sized spiny neurons, the primary striatal projection neurons lost after stroke. Our results suggest that adult neuroblasts do not alter their intrinsic differentiation potential after brain injury.

\section{Introduction}

The generation of new neurons (neurogenesis) from neural stem cells normally occurs in two regions of the adult mammalian brain, the hippocampal dentate gyrus and the olfactory bulb (OB) (Alvarez-Buylla and Lim, 2004; Ming and Song, 2005; Zhao et al., 2008). The persistence of neurogenesis throughout life raises the possibility that the resident neural stem cells can mount a regenerative response to replace neurons lost after brain injury. Indeed, studies have shown that stroke increases the production of new neurons in the damaged striatum that are derived from neural progenitor cells in the adjacent subventricular zone (SVZ) of the adult brain (Arvidsson et al., 2002; Parent et al., 2002; Jin et al., 2003; Teramoto et al., 2003; Thored et al., 2006; Yamashita et al., 2006). The therapeutic value of this regenerative response to brain injury has been questioned. A key point toward evaluating their therapeutic potential is establishing whether the progenitor cells that persist into adulthood retain the capacity to differentiate into the spectrum of cell types that were damaged.

Neurons in the striatum are diverse. Approximately 90-95\% of the neurons in the striatum are GABAergic medium-sized spiny projection neurons and $5-10 \%$ are local interneurons.

\footnotetext{
Received Jan. 14, 2009; revised Feb. 21, 2009; accepted March 10, 2009.

This work was funded by the 985 -II Program sponsored by the Ministry of Education of China, National Natural Science Foundation of China (Grant 30870804), the Pujiang Talent Project of the Shanghai Science and Technology Committee (Grant 07PJ14015), and the Innovation Program of Shanghai Municipal Education Commission (Grant 08Zz01). We thank David Saffen (Fudan University, Shanghai, People's Republic of China) for helpful comments on this manuscript. We also thank two anonymous reviewers for their comments, which helped improve this study.

${ }^{*}$ F.L. and Y.Y. contributed equally to this work.

Correspondence should be addressed to Dr. Zhengang Yang, Institutes of Brain Science and State Key Laboratory of Medical Neurobiology, Fudan University, 138 Yi Xue Yuan Road, 200032 Shanghai, People's Republic of China. E-mail: yangz@fudan.edu.cn.

D01:10.1523/JNEUROSC1.0201-09.2009

Copyright $\odot 2009$ Society for Neuroscience $\quad$ 0270-6474/09/295075-13\$15.00/0
}

DARPP-32 is expressed in virtually all of the striatal mediumsized spiny projection neurons (Ouimet et al., 1998) and the calcium-binding protein calbindin (CB) also is a selective marker for these cells (Liu and Graybiel, 1992). In contrast, striatal interneurons are a heterogeneous group, comprising four nonoverlapping populations that have been classified as positive for parvalbumin $\left(\mathrm{PV}^{+}\right)$, calretinin $\left(\mathrm{CR}^{+}\right)$, somatostatin $\left(\mathrm{SOM}^{+}\right)$, and choline acetyltransferase $\left(\mathrm{ChAT}^{+}\right)$(Kawaguchi et al., 1995; Marin et al., 2000). The mosaic organization of striatal neurons offers opportunities to study the plasticity of neural stem cells and their descendants (neuroblasts) in the adjacent SVZ after brain injury, which we evaluated using a rat model for ischemic stroke (Koizumi et al., 1986; Longa et al., 1989; Arvidsson et al., 2002).

\section{Materials and Methods}

Induction of ischemic stroke. Adult male Sprague Dawley rats (SD, $\sim 250 \mathrm{~g}$, 8 weeks old; Shanghai SLAC Laboratory Animal Co. Ltd.) were used for the experiment. We certify that all experiments using animals were performed in accordance with institutional guidelines, and We further attest that all efforts were made to minimize the number of animals used and their suffering. Rats were anesthetized with intraperitoneal injections of chloral hydrate $(360 \mathrm{mg} / \mathrm{kg}$, body weight) and transient middle cerebral artery occlusion (MCAO) was induced by the intraluminal filament technique as previously described (Koizumi et al., 1986; Longa et al., 1989; Arvidsson et al., 2002). Briefly, the right common carotid artery (CCA) and external carotid artery were permanently ligated, and the MCA was occluded by a nylon monofilament inserted through the CCA. The filament was secured and rats allowed to wake up. After $2 \mathrm{~h}$ of occlusion, the filament was withdrawn. No blood loss occurred during occlusion or reperfusion. Approximately, $60 \%$ of the animals sustained infarcts that involved the ipsilateral striatum and only these animals were used in this study.

BrdU injections. The S-phase marker 5-bromo-2'-deoxyuridine (BrdU) $(50 \mathrm{mg} / \mathrm{kg}$ body weight, Sigma) was injected intraperitoneally 
Table 1. Primary antibodies used for immunohistochemistry

\begin{tabular}{|c|c|c|c|}
\hline Antibody & Species & Dilution & Source (catalog number) \\
\hline Human placental alkaline phosphatase & Rabbit antiserum & $1: 30$ & Accurate Chemical (YSRTAHP537) \\
\hline 5-Bromo-2'-deoxyuridine & Rat monoclonal lgG2a & $1: 30$ & Accurate Chemical (OBT0030S) \\
\hline Calbindin D-28K & Mouse monoclonal lgG1 & $1: 10,000$ & Swant (300) \\
\hline Calretinin & Mouse monoclonal lgG1 & $1: 400$ & Millipore (MAB1568) \\
\hline Calretinin & Rabbit antiserum & $1: 4000$ & Millipore (AB5054) \\
\hline Choline acetyltransferase & Mouse monoclonal lgG1 & $1: 100$ & Millipore (MAB305) \\
\hline COUP TF1-interacting protein 2 & Rat monoclonal & $1: 200$ & Abcam (ab18465) \\
\hline DARPP-32 & Rabbit polyclonal & $1: 100$ & Cell Signaling Technology (2302) \\
\hline DARPP-32 & Goat polyclonal & $1: 50$ & Santa Cruz Biotechnology (sc-8066) \\
\hline Doublecortin & Goat polyclonal & $1: 100$ & Santa Cruz Biotechnology (sc-8483) \\
\hline Forkhead box P1 & Rabbit polyclonal & $1: 300$ & Abcam (ab16645) \\
\hline Glial fibrillary acidic protein & Mouse monoclonal lgG1 & $1: 300$ & Millipore (MAB360) \\
\hline Green fluorescent protein & Chicken polyclonal lgY & $1: 500$ & Aves Labs (GFP-1020) \\
\hline Islet1 & Rabbit polyclonal & $1: 200$ & Abcam (ab20670) \\
\hline NeuN & Mouse monoclonal lgG1 & $1: 300$ & Millipore (MAB377) \\
\hline Parvalbumin & Mouse monoclonal lgG1 & $1: 400$ & Millipore (MAB1572) \\
\hline Sp8 & Rabbit polyclonal & $1: 20,000$ & Millipore (AB15260) \\
\hline $\mathrm{Pbx}$ & Rabbit polyclonal & $1: 80$ & Santa Cruz Biotechnology (sc-888) \\
\hline Somatostatin & Rabbit polyclonal & $1: 50$ & Santa Cruz Biotechnology (sc-13099) \\
\hline Somatostatin & Mouse monoclonal & $1: 100$ & GeneTex (GTX71935) \\
\hline Tyrosine hydroxylase & Mouse monoclonal $\lg G 1 \kappa$ & $1: 400$ & Millipore (MAB318) \\
\hline
\end{tabular}

twice daily during days 3-7 after stroke (totally $5 \mathrm{~d}$ for 10 times). Animals were perfused 2 weeks, 6 weeks, or 6 months after stroke. In a parallel experiment, BrdU was also given intraperitoneally twice daily during days 1-14 after stroke and animals were perfused at 6 weeks recovery from stroke.

Virus injections. Replication-incompetent retroviruses encoding the marker gene human placental alkaline phosphatase (AP) were harvested from the psi2 DAP cell line (ATCC CRL-1949) concentrated, titered, and tested for helper virus as described previously (Levison and Goldman, 1993). The titer was $1 \sim 2 \times 10^{9}$ colony-forming units $/ \mathrm{ml}$. High titers $\left(1 \times 10^{9}\right.$ units $\left./ \mathrm{ml}\right)$ of self-inactivating lentiviruses encoding the marker gene GFP were produced by GeneChem, CO Ltd.. One day before stroke, SD rats were anesthetized and totally $2 \mu \mathrm{l}$ of retroviruses or lentiviruses with $8 \mu \mathrm{g} / \mathrm{ml}$ polybrene were injected stereotaxically in 2 coordinates (1 $\mu \mathrm{l} / \mathrm{site})$ for each SVZ [unit $(\mathrm{mm})$ relative to bregma, anterior, +2.0; lateral, \pm 1.1 ; depth, 4.6; and anterior, +0.2 ; lateral, \pm 2.0 ; depth, 3.4] (Paxinos and Watson, 1998). Rats were killed 2 d, 2 weeks, and 6 weeks after stroke. Sections $(40 \mu \mathrm{m})$ at $240 \mu \mathrm{m}$ intervals were collected and processed for either AP histochemistry, AP or GFP immunofluorescence in combination with neuronal markers (Wichterle et al., 2001; Merkle et al., 2007).

Immunohistochemistry. Animals were deeply anesthetized with chloral hydrate $(400 \mathrm{mg} / \mathrm{kg}$ body weight, i.p.) before intracardiac perfusion with $0.9 \%$ saline followed by $4 \%$ paraformaldehyde. Brains were postfixed with $4 \%$ paraformaldehyde overnight and then cryoprotected for at least $24 \mathrm{~h}$ in $30 \%$ sucrose in PBS. The brain samples were frozen in embedding medium (O.C.T., Sakura Finetek) on a dry ice/ethanol slush.

Immunohistochemistry staining was performed on $40 \mu \mathrm{m}$ free floating sections in 24-well tissue culture plates or $10 \mu \mathrm{m}$ sections on Superfrost plus slides (Fisher Scientific). Sections $(10 \mu \mathrm{m})$ were mainly used for immunostaining on embryonic day 16 (E16) rat brains. Some $10 \mu \mathrm{m}$ sections of the adult rat brain were also used to reduce background levels for $\mathrm{Sp} 8$ immunostaining. Sections for BrdU staining were pretreated with $2 \mathrm{~N} \mathrm{HCl}$ for $1 \mathrm{~h}$ at room temperature to denature DNA. Sections were blocked for $1 \mathrm{~h}$ in TBS with $0.3 \%$ Triton X-100 and 10\% donkey serum. Primary antibodies were incubated for $24 \mathrm{~h}$ at $4^{\circ} \mathrm{C}$ (the Sp8 antibody was incubated for $48-72 \mathrm{~h}$ ). The antibodies used in this study are described in Table 1. All antibodies are available commercially.

Secondary antibodies against the appropriate species were incubated for $2 \mathrm{~h}$ at RT (all from The Jackson Laboratory, 1:200). All secondary antibody combinations were carefully examined to ensure that there was no cross talk between fluorescent dyes or cross-reactivity between secondary antibodies, especially for anti-rat and anti-mouse secondary antibodies. Fluorescently stained sections were then washed, counterstained with 4',6'-diamidino-2-phenylindole (DAPI) (Sigma, $1 \mu \mathrm{g} / \mathrm{ml}$ ) for $5 \mathrm{~min}$, and coverslipped with Gel/Mount (Biomeda). Streptavidin and diaminobenzidine (DAB) were used to visualize the reaction product for bright-field staining sections. Omission of primary antibodies eliminated staining.

Microscopy. Fluorescently immunolabeled sections were analyzed on a Zeiss LSM510 confocal laser scanning microscope using the following filter sets with the indicated wavelengths (in $\mathrm{nm}$ ) for the excitation laser line and emission filters: DAPI, 405/(LP 420); Cy2, 488/(505/530); Cy3, 543/(560-615); Cy5, 633/(LP 650). Confocal Z sectioning was performed at $0.5 \mu \mathrm{m}$ intervals using a Plan-Apochromat $\times 63(\mathrm{NA}=1.40)$ oil-immersion objective for single, double, and triple labeling. Images were acquired and a Z-stack was reconstructed using the Zeiss LSM software, cropped, adjusted and optimized in Photoshop 9.0. Images of enzyme histochemistry labeled sections and some fluorescently immunolabeled sections were acquired using an Olympus BX 51 microscope.

Cell quantification. Animals given BrdU intraperitoneal injections twice daily during days 3-7 after stroke (totally $5 \mathrm{~d}$ for 10 times) were used for cell quantification.

The number of $\mathrm{CR}^{+}$cells in bright-field staining sections of the contralateral or ipsilateral striatum 6 months after stroke, were counted using a $\times 40$ objective. Because the posterior part of the striatum was absent or severely reduced in size, rostral striatal regions were used for quantification. Coronal sections were collected from the anterior tip of the corpus callosum (Paxinos and Watson, 1998). Six $40 \mu \mathrm{m}$ sections at $240 \mu \mathrm{m}$ intervals (every 6 sections) were quantified per brain ( $n=5$ rats). Briefly, in each section, the entire striatal cross- section was scanned on the right and left, and all $\mathrm{CR}^{+}$neurons were visualized by focusing up and down. Neurons were counted if they contained a whole cell body. The number presented was calculated by multiplying the number of $\mathrm{CR}^{+}$cells counted per section and 6 sections.

To compare the number of newly born immature neurons in the contralateral and ipsilateral striatum 2 weeks after stroke, $\mathrm{BrdU}^{+} / \mathrm{dou}-$ blecortin $(\mathrm{Dcx})^{+}$cells were counted with an epifluorescence microscope using a $\times 40$ objective. Four $40 \mu \mathrm{m}$ sections at $480 \mu \mathrm{m}$ intervals (every 12 sections) of each brain were quantified ( $n=5$ rats). To compare the number of $\mathrm{BrdU}^{+} / \mathrm{CR}^{+}$cells in the $\mathrm{OB}$ of the contralateral or ipsilateral brain, four $40 \mu \mathrm{m}$ sagittal sections at $240 \mu \mathrm{m}$ (every 6 sections) of each OB were counted with a $\times 40$ objective $(n=3$ rats). The number presented was calculated by multiplying the number of double-labeled cells counted per section and 4 sections.

$\mathrm{BrdU}^{+} / \mathrm{NeuN}^{+}$or $\mathrm{BrdU}{ }^{+} / \mathrm{CR}^{+}$in the striatum was counted using a Zeiss LSM510 confocal laser scanning microscope. We recently developed a new method to more accurately count the BrdU-labeled newly 


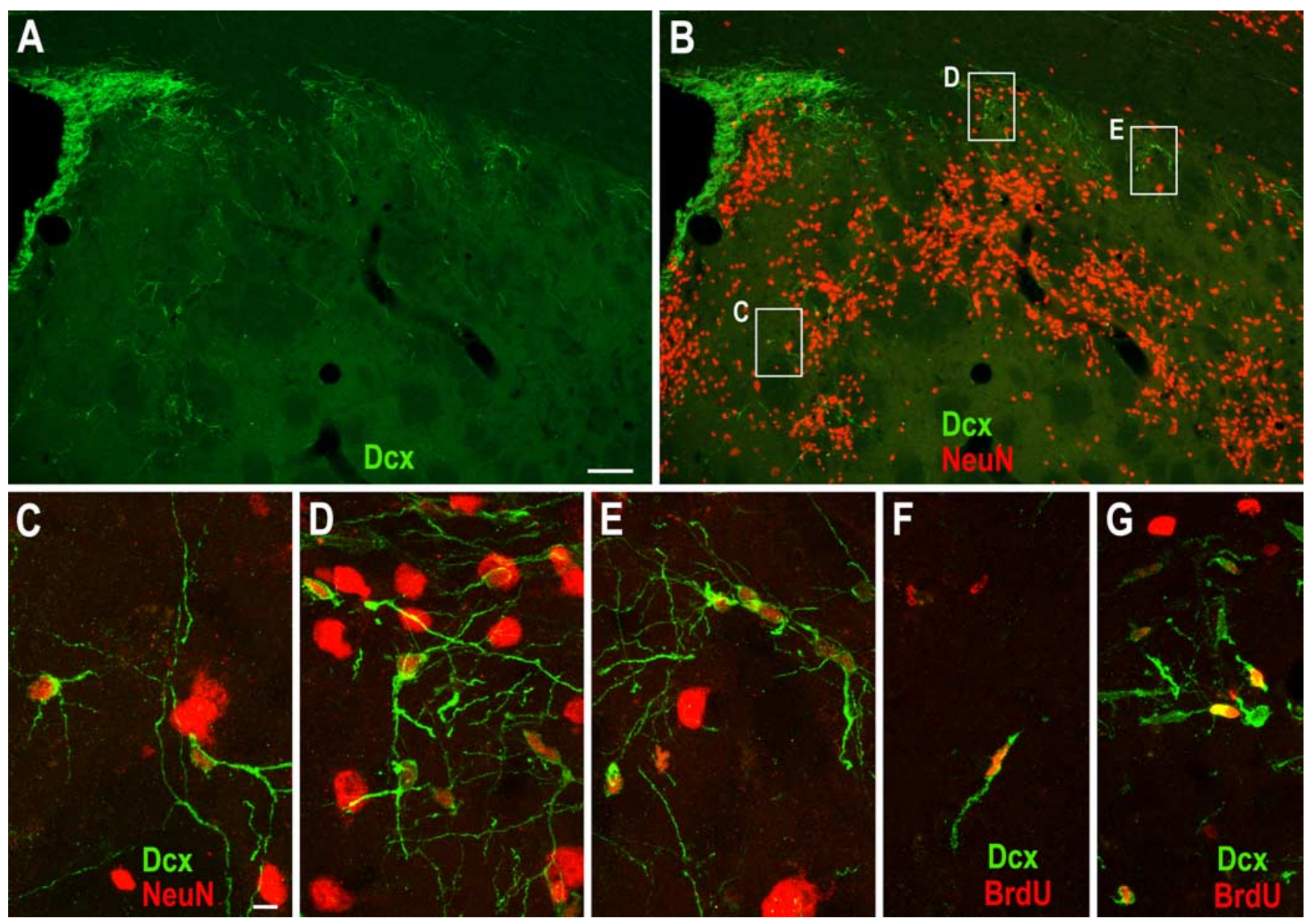

Figure 1. $D c x^{+}$immature neurons are abundant in the damaged striatum after stroke. $\boldsymbol{A}, \boldsymbol{B}$, Photomicrographs of $D c x(\boldsymbol{A})$ and $D x \times /$ NeuN double $(\boldsymbol{B})$ immunostaining in the damaged striatum 2 weeks after stroke. $\boldsymbol{C}-\boldsymbol{E}$, Higher magnification of the boxed areas in $\boldsymbol{B}$ showing $\mathrm{Dcx}{ }^{+} / \mathrm{NeuN}^{+}$cells. $\boldsymbol{F}, \mathbf{G}, \mathrm{BrdU}$ was injected intraperitoneally twice daily during days $3-7$ after stroke and BrdU/Dcx double immunostaining

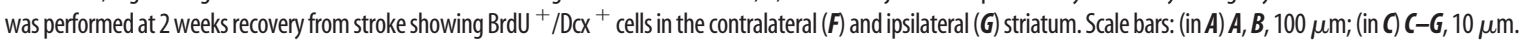

born small interneuron-like cells in the damaged striatum (Yang and Levison, 2007; Yang et al., 2008). In current study, four $40 \mu \mathrm{m}$ sections at $480 \mu \mathrm{m}$ (every 12 sections, the first section was collected from the anterior tip of the corpus callosum) of each striatum were extensively analyzed ( $n=4$ rats, 6 weeks poststroke; $n=5$ rats, 6 months poststroke). For each section, confocal $\mathrm{Z}$ sectioning was performed at $1.0 \mu \mathrm{m}$ intervals using a Plan-Neofluar $\times 40(\mathrm{NA}=1.30)$ oil-immersion objective in each field (covers $300 \mu \mathrm{m} \times 300 \mu \mathrm{m}$ ) and 10 fields were quantified. Ten fields at fixed intervals $(100-300 \mu \mathrm{m}$; depends on the striatal area of the contralateral and ipsilateral hemisphere) were equally distributed in each section. The total volume analyzed of each striatum was 10 fields $\times 4$ sections $\times 40 \mu \mathrm{m}$ section thickness $\times 300 \mu \mathrm{m} \times 300 \mu \mathrm{m}=0.144 \mathrm{~mm}^{3}$. The number presented was calculated by multiplying the number of double-labeled cells counted per field and 10 fields and 4 sections.

The longest axis of DARPP $-32^{+}, \mathrm{BrdU}^{+} / \mathrm{CR}^{+}, \mathrm{CR}^{+} / \mathrm{Sp} 8{ }^{-}$, and $\mathrm{CR}^{+} / \mathrm{Sp} 8{ }^{+}$cell bodies were measured with an epifluorescence microscope using a $\times 100$ objective. We analyzed an average of $422( \pm 171)$ cells in at least 3 rats.

Statistical analysis. All data are presented as the means \pm SEM. We analyzed numeric data for statistical significance using Student's $t$ test with SAS Institute software. We considered $p$ values $<0.05$ as statistically significant.

\section{Results}

Ischemic stroke induces production of $\mathrm{CR}^{+}$cells in the damaged striatum

Ischemic stroke was induced by transient middle cerebral artery occlusion (MCAO) in adult rats as described previously (Arvids- son et al., 2002). We first evaluated Dcx expression in the striatum because this neuronal microtubule-associated protein is expressed by virtually all neuroblasts and immature neurons and has been used in numerous studies as a marker for adult neurogenesis. $\mathrm{Dcx}^{+}$cells are rare within the striatum of contralateral (intact) or normal control brain (Arvidsson et al., 2002; Parent et al., 2002). However, at 2 weeks after stroke, an increase in Dcx immunostaining is readily visible in the ipsilateral striatum (Fig. $1 A$ ). Most of these $\mathrm{Dcx}^{+}$cells possessed morphologies characteristic of migrating neuroblasts and were interspersed between the SVZ and the damaged striatum (Fig. $1 A-E$ ). When the S-phase marker BrdU was injected intraperitoneally for $5 \mathrm{~d}$ beginning at day 3 after induction of stroke to label newly born cells and BrdU/ Dcx double immunofluorescence performed after 2 weeks of recovery, we observed more $\mathrm{BrdU}^{+} / \mathrm{Dcx}^{+}$cells in the ipsilateral striatum compared with contralateral striatum (Fig. 1F, G; $10.4 \pm 2.3$ vs $422 \pm 18.8$ cells in the contralateral vs ipsilateral striatum; $p=0.0001$ by Student's $t$ test, $n=5$ rats). This result is consistent with previous observations (Arvidsson et al., 2002; Parent et al., 2002; Jin et al., 2003; Teramoto et al., 2003; Thored et al., 2006; Yamashita et al., 2006).

As the range of neuronal subtypes produced after stroke has not been established, we phenotyped these newly produced striatal neurons using a panel of neuronal markers. Very few $\mathrm{BrdU}^{+}$/ $\mathrm{NeuN}^{+}$cells (mature neurons) were found in the damaged stri- 
atum 2 weeks after stroke ( 1 week after the last BrdU injection). However, $\mathrm{BrdU}^{+} /$ $\mathrm{NeuN}^{+}$cells were readily identified in the damaged striatum compared with the contralateral striatum after 6 weeks recovery from stroke (Fig. $2 A ; 1.3 \pm 0.5$ vs $21 \pm 4.1$ cells $/ 0.144 \mathrm{~mm}^{3}$ in the contralateral vs ipsilateral striatum; see Materials and Methods for details; $p=0.02$ by Student's $t$ test, $n=4$ rats). To our surprise, we were unsuccessful in identifying BrdU-labeled neurons that possessed the morphological or phenotypic features of medium-sized spiny neurons $\left(\mathrm{BrdU}^{+} / \mathrm{DARPP}-32^{+}\right.$or $\mathrm{BrdU}^{+} / \mathrm{CB}^{+}$cells) (Fig. $2 \mathrm{~B}, \mathrm{C}$ ). We also did not find $\mathrm{BrdU}^{+}$cells labeled for $\mathrm{PV}^{+}$, $\mathrm{SOM}^{+}$or $\mathrm{ChAT}^{+}$(Fig. 2D-F). Because neural progenitor cells in the SVZ give rise to a very small number of dopaminergic periglomerular cells (that tyrosine hydroxylase positive, $\mathrm{TH}^{+}$) in the adult $\mathrm{OB}$, we also performed $\mathrm{TH}$ immunostaining. Neither single $\mathrm{TH}^{+}$nor $\mathrm{BrdU}^{+} / \mathrm{TH}^{+}$cells were found in the contralateral or ipsilateral striatum (Fig. 2G). In contrast, $\mathrm{BrdU}^{+} / \mathrm{CR}^{+}$cells were abundant in the damaged striatum compared with the intact striatum (Fig. $2 H ; 3.3 \pm 1.3$ vs $23.3 \pm$ 5.6 cells $/ 0.144 \mathrm{~mm}^{3}$ in the contralateral vs ipsilateral striatum; $p=0.02$ by Student's $t$ test, $n=4$ rats). The densities of $\mathrm{BrdU}^{+}$/ $\mathrm{NeuN}^{+}$cells and BrdU ${ }^{+} / \mathrm{CR}^{+}$cells in damaged striatum were similar ( 21 vs 23 cells/ $0.144 \mathrm{~mm}^{3}$ respectively). In fact, we found most of the BrdU-labeled $\mathrm{CR}^{+}$cells expressed NeuN and vice versa (Fig. $2 I-N$ ).

The longest axis of $\mathrm{BrdU}^{+} / \mathrm{CR}^{+}$cell bodies ranged from 5 to $13 \mu \mathrm{m}$ (7.64 \pm $0.12 \mu \mathrm{m} ; n=4$ rats). Because the longest axis of medium-sized spiny neurons (DARPP $-32^{+}$) in adult rats ranged from 8 to $16 \mu \mathrm{m}(12.0 \pm 0.13 \mu \mathrm{m}, n=3$ rats $)$, our results suggest the newly born $\mathrm{CR}^{+}$cells induced by stroke belong to class of small interneurons in the striatum.

BrdU given intraperitoneally twice daily for $5 \mathrm{~d}$ after stroke may miss to label relatively quiescent neural stem cells of the adult SVZ, with a predicted cell cycle time of $28 \mathrm{~d}$ (Morshead et al., 1994). Therefore, in another 5 rats, BrdU was given intraperitoneally twice daily during days 1-14 after stroke. Although more $\mathrm{BrdU}^{+} / \mathrm{NeuN}^{+}$and $\mathrm{BrdU}{ }^{+} / \mathrm{CR}^{+}$cells were easily found (Fig. $2 \mathrm{O}, \mathrm{P})$, no $\mathrm{BrdU}^{+} / \mathrm{DARPP}-32^{+}$or $\mathrm{BrdU}{ }^{+} / \mathrm{CB}^{+}$cells were detected in the damaged striatum of these animals 6 weeks after stroke.

\section{$\mathrm{CR}^{+}$cells in the damaged striatum are derived from the SVZ}

To establish whether these newly born $\mathrm{CR}^{+}$small interneuronlike cells are descendants of SVZ progenitor cells, we labeled dividing cells by injecting replication-incompetent retroviruses (DAP retrovirus) encoding the marker gene alkaline phosphatase (AP) into the SVZ $1 \mathrm{~d}$ before inducing stroke. Two days after injections, most AP-labeled cells in the contralateral hemisphere were located within the SVZ (Fig. 3A), whereas, in the ipsilateral
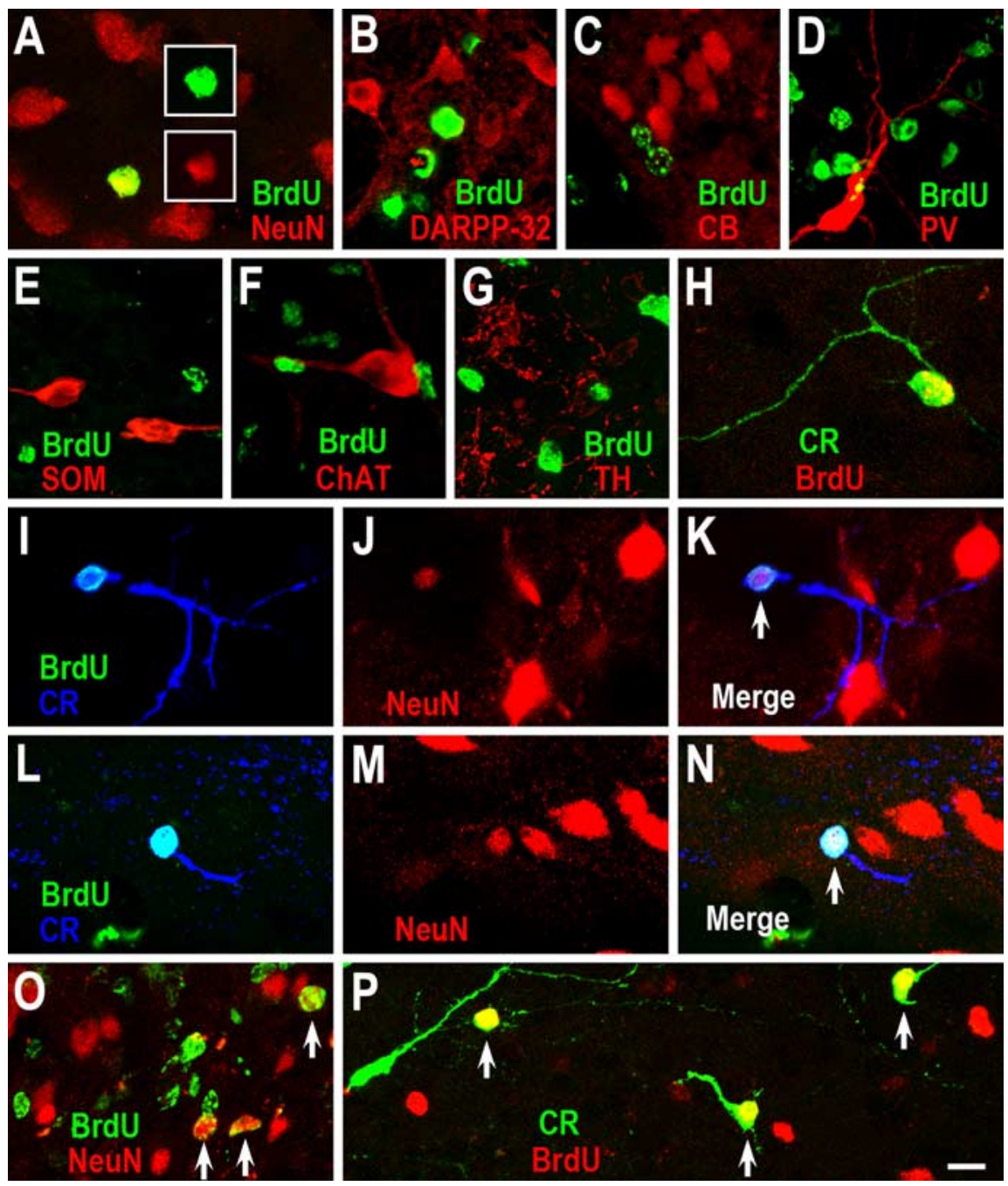

Figure 2. $\quad \mathrm{New} \mathrm{CR}^{+}$cells are generated in the damaged striatum after stroke. $\boldsymbol{A}-\boldsymbol{H}$, BrdU was injected intraperitoneally twice daily on days 3-7 of recovery from stroke and BrdU was combined with immunostaining for neuronal markers at 6 weeks after (A) and BrdU ${ }^{+} / \mathrm{CR}^{+}(\boldsymbol{H})$, but not BrdU ${ }^{+} / \mathrm{DARPP}-32(\boldsymbol{B}), \mathrm{BrdU}^{+} / \mathrm{CB}(\boldsymbol{C}), \mathrm{BrdU}^{+} / \mathrm{PV}^{+}(\boldsymbol{D})$, Br arrows) in the damaged striatum 6 weeks after stroke. Note that NeuN protein is lightly expressed in one newborn $\left(R^{+}\right.$ for neuronal markers at 6 weeks after stroke. BrdU ${ }^{+} / \mathrm{NeuN}^{+}$cells $\left(\mathbf{0}\right.$, arrows) and BrdU ${ }^{+} / \mathrm{CR}^{+}$cells $(\boldsymbol{P}$, arrows) are more abundant in the damaged striatum. Scale bar: (in $\boldsymbol{P}) \boldsymbol{A}-\boldsymbol{P}, 10 \mu \mathrm{m}$.

hemisphere, some AP-labeled cells had migrated out the SVZ and into the damaged striatum (Fig. 3B). AP/Dcx double immunostaining showed that most AP-labeled cells expressed Dcx (Fig. $3 C, D)$. These cells had the typical morphology of migrating neuroblasts, i.e., an oval or elongated cell body with a leading process (Petreanu and Alvarez-Buylla, 2002). Six weeks after stroke, $85 \pm$ $4 \%$ of AP-labeled cells with interneuronal morphologies were $\mathrm{CR}^{+}$in the damaged striatum (156 cells, 3 rats) (Fig. 3E-J).

Previous studies have suggested that most of the cells labeled by a single injection of DAP retrovirus correspond to the dividing neuroblasts and transit amplifying progenitors, but not the more slowly dividing neural stem cells (Petreanu and Alvarez-Buylla, 2002; Geraerts et al., 2006). Indeed, very few AP-labeled cells were seen in the SVZ and rostral migratory stream (RMS) of the rats 6 weeks after stroke (data not shown). To label both dividing and nondividing cells in the SVZ, we injected self-inactivating lentiviruses expressing GFP into the adult rat SVZ $1 \mathrm{~d}$ before inducing stroke. Two weeks after stroke, many $\mathrm{GFP}^{+}$cells were scattered within the damaged 

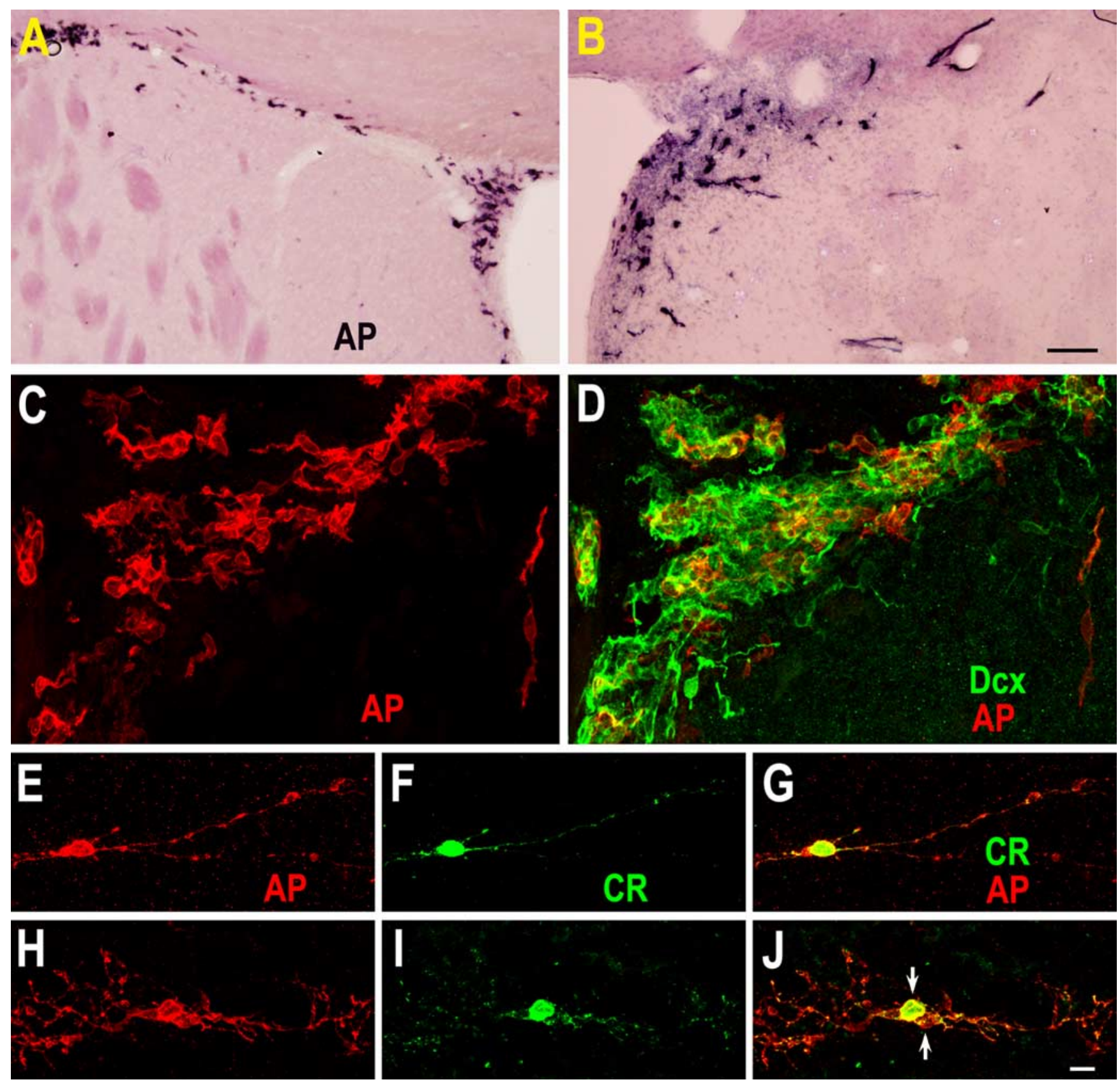

Figure 3. Retrovirus-labeled SVZ-derived cells in the damaged striatum 6 weeks after stroke express CR. $A, B$, To label dividing cells, replication-incompetent retroviruses encoding the marker gene alkaline phosphatase (AP) were bilaterally injected into the SVZ $1 \mathrm{~d}$ before inducing stroke. AP histochemistry staining in the contralateral $(\boldsymbol{A})$ and ipsilateral $(\boldsymbol{B})$ SVZ and AP/Dcx double immunostaining $(\boldsymbol{C}, \boldsymbol{D})$ were performed $2 \mathrm{~d}$ after injection. Note that most AP-labeled cells are located within the SVZ of the contralateral hemisphere $(\boldsymbol{A})$, whereas some AP-labeled cells have migrated out of the SVZ and into the damaged striatum of the ipsilateral hemisphere $(\boldsymbol{B}, \boldsymbol{D}) 2 \mathrm{~d}$ after injection. Myelin is weakly stained with the BCIP/NBT in the contralateral (intact) striatum. $\boldsymbol{E}-J, \mathrm{AP}^{+} / \mathrm{CR}^{+}$cells in the damaged striatum 6 weeks after stroke. Note that two $\mathrm{AP}^{+} / \mathrm{CR}^{+}$cells (J, arrows) are morphologically alike, and may have been generated from a single progenitor cell. Scale bars: (in $B$ ) $A, B, 100 \mu \mathrm{m}$; (in $\left.\int\right)(-J, 10 \mu \mathrm{m}$.

striatum and $90.2 \pm 7 \%$ of $\mathrm{GFP}^{+}$cells expressed Dcx (563 cells, 3 rats) (Fig. 4). By 6 weeks after stroke, GFP/CR double immunostaining showed that $79.8 \pm 6 \%$ of the GFP-labeled cells were $\mathrm{CR}^{+}$in the damaged striatum (381 cells, 3 rats) (Fig. 5), although there were a small number of GFP-labeled cells that weakly expressed CR protein (Fig. $5 E$ ). Moreover, some $\mathrm{GFP}^{+} / \mathrm{CR}^{+}$cells were located several millimeters from the SVZ (Fig. 5G). Again confirming the BrdU results, we did not find any AP- or GFP-labeled cells that expressed DARPP-32, CB, PV, SOM or ChAT.

In accordance with published results (Geraerts et al., 2006), we also found that, in contrast to DAP retrovirus, lentivirus-labeled cells remained present in the SVZ 6 weeks after stroke. Confocal analysis showed that some GFP-labeled cells in the SVZ were positive for GFAP (Fig. 5H-J), a marker for primary neurogenic stem cells. Moreover, many $\mathrm{GFP}^{+} / \mathrm{Dcx}^{+}$cells were still observed in the SVZ and RMS 6 weeks after stroke (Fig. $5 \mathrm{~K}-\mathrm{O}$ ) further indicating that some slowly dividing neural stem cells were indeed labeled by stereotactic injection of lentivirus into the SVZ.

\section{Newly born immature neurons in the damaged striatum express CR after stroke}

There was also a visible increase in the number of $\mathrm{Dcx}^{+} / \mathrm{NeuN}^{+}$ cells in the ipsilateral striatum 2 and 6 weeks after stroke (Fig. $1 C-E)$, suggesting that $\mathrm{Dcx}^{+}$cells generated from the SVZ before 


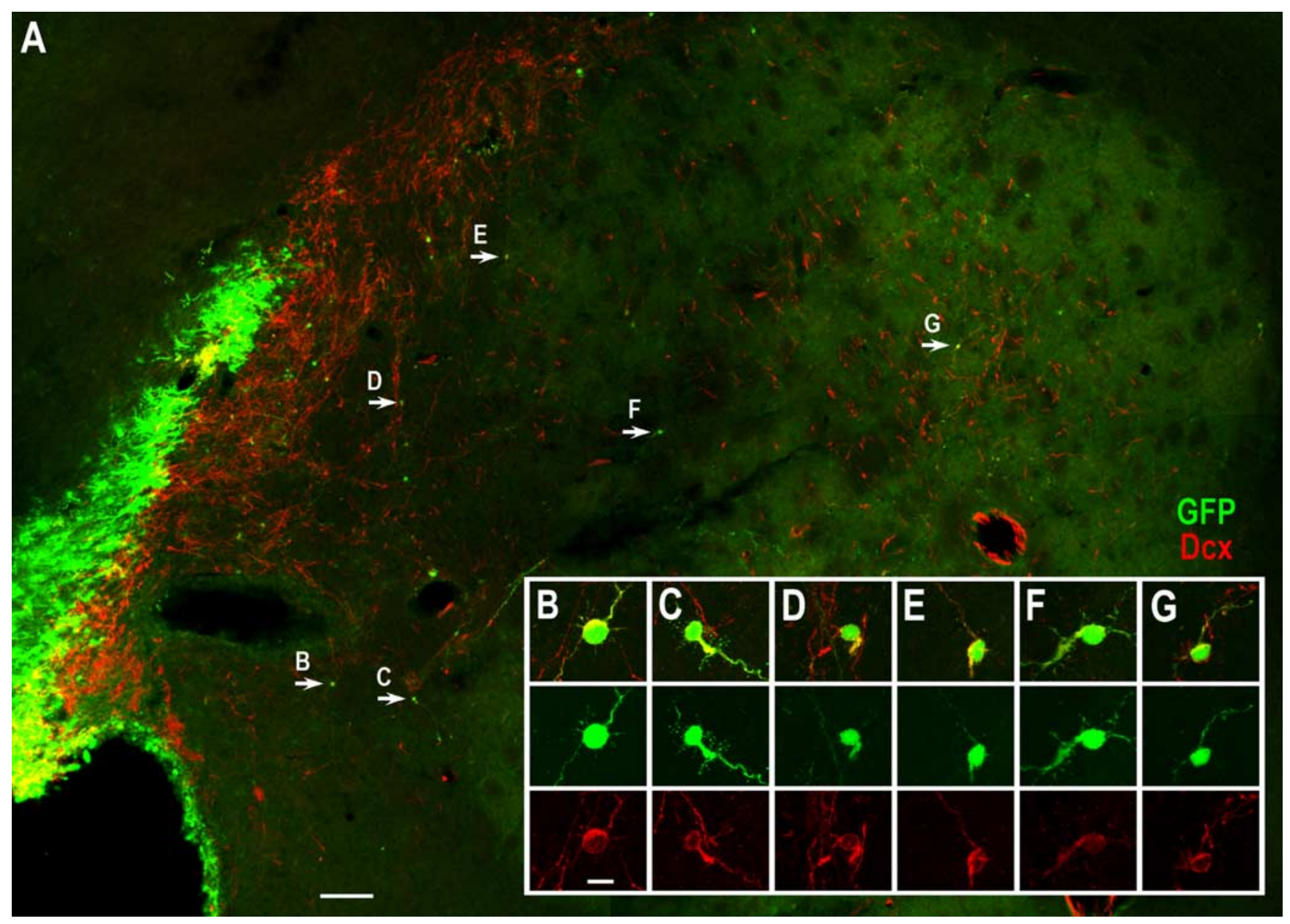

Figure 4. Lentivirus-labeled SVZ-derived cells in the damaged striatum 2 weeks poststroke express Dcx. A, Self-inactivating lentiviruses expressing GFP were injected into the SVZ $1 \mathrm{~d}$ before inducing stroke and GFP/Dcx double immunostaining was performed 2 weeks after stroke showing that most GFP-labeled cells in the damaged striatum express $D c x$. $\boldsymbol{B}-\boldsymbol{G}$, Higher magnification of $\mathrm{GFP}^{+} / \mathrm{Dcx}^{+}$cells in $\boldsymbol{A}$ (arrows). Scale bars: $\boldsymbol{A}, 100 \mu \mathrm{m}$; (in $\left.\boldsymbol{B}\right) \boldsymbol{B}-\mathbf{G}, 10 \mu \mathrm{m}$.

or after stroke were maturing within the damaged striatum. Because Dcx is expressed by virtually all newborn young, maturing neurons, regardless whether they are derived from slowly dividing neural stem cells or rapid dividing progenitors, we performed immunostaining for Dcx in combination with striatal neuronal markers to identify the phenotype of the new neurons generated after stroke. Again, 2 weeks poststroke, $>30 \%$ of the single Dcx ${ }^{+}$ cells in the damaged striatum expressed CR (672 cells, 4 rats) (Fig. $6 A-E)$. None, however, expressed DARPP-32, CB, PV, SOM or ChAT. Together, these results indicate that after stroke, neuroblasts derived from neural progenitor cells in the SVZ migrate into the damaged striatum where they differentiate into $\mathrm{CR}^{+}$ interneuron-like cells.

The migration of large numbers of SVZ-derived $\mathrm{CR}^{+}$cells into the damaged striatum after stroke raises the possibility that production of newly born $\mathrm{CR}^{+}$cells in the $\mathrm{OB}$ may be reduced. To address this question, we examined the distribution of $\mathrm{CR}^{+}$ cells in the RMS and OB 2 weeks after stroke. Surprisingly, we found that there were many $\mathrm{Dcx}^{+} / \mathrm{CR}^{+}$cells in the RMS, its surroundings and the $\mathrm{OB}$ (Fig. $6 F-K$ ), but there was no visible difference in distribution of $\mathrm{CR}^{+}$cells between the contralateral (or normal control) and ipsilateral RMS and OB. We also injected BrdU intraperitoneally twice daily during days 3-7 after stroke to label newly born neurons in the OB. Six weeks after stroke, there was also no significant difference between the number of $\mathrm{BrdU}^{+}$/
$\mathrm{CR}^{+}$cells in granular cell layers $(342 \pm 22.5$ vs $407.7 \pm 18.9$ cells in the contralateral vs ipsilateral OB; $p=0.25$ by Student's $t$ test, $n=3$ rats) or glomerular layers ( $339.3 \pm 47.8$ vs $288 \pm 14$ cells in contralateral vs ipsilateral OB; $p=0.47$ by Student's $t$ test, $n=3$ rats). This is not surprising considering that $>50 \%$ of new cells are lost after they migrate into the $\mathrm{OB}$, suggesting that new neurons are produced in excess in the $\mathrm{OB}$ and then later selected for survival (Petreanu and Alvarez-Buylla, 2002). Moreover, previous studies have shown that SVZ progenitor cells first proliferate after stroke (Arvidsson et al., 2002; Parent et al., 2002). Thus, the number of newly born $\mathrm{CR}^{+}$cells in the $\mathrm{OB}$ seemed unaffected by stroke.

\section{$\mathrm{CR}^{+}$cells accumulate in the ipsilateral striatum at long} recovery times after stroke

Many Dcx ${ }^{+}$cells in the ipsilateral striatum could be still observed after 6 months recovery from stroke (supplemental Fig. 1, available at www.jneurosci.org as supplemental material), suggesting that adult striatal neurogenesis after ischemic injury is sustained for several months (Kokaia et al., 2006; Thored et al., 2006). If only CR-expressing cells were generated, continued neurogenesis should induce more CR-expressing cells in the ipsilateral striatum after long term recovery from stroke. As anticipated, we observed a large number of $\mathrm{CR}^{+}$cells in the damaged striatum 6 months after stroke (Fig. 7). These $\mathrm{CR}^{+}$cells were either clus- 


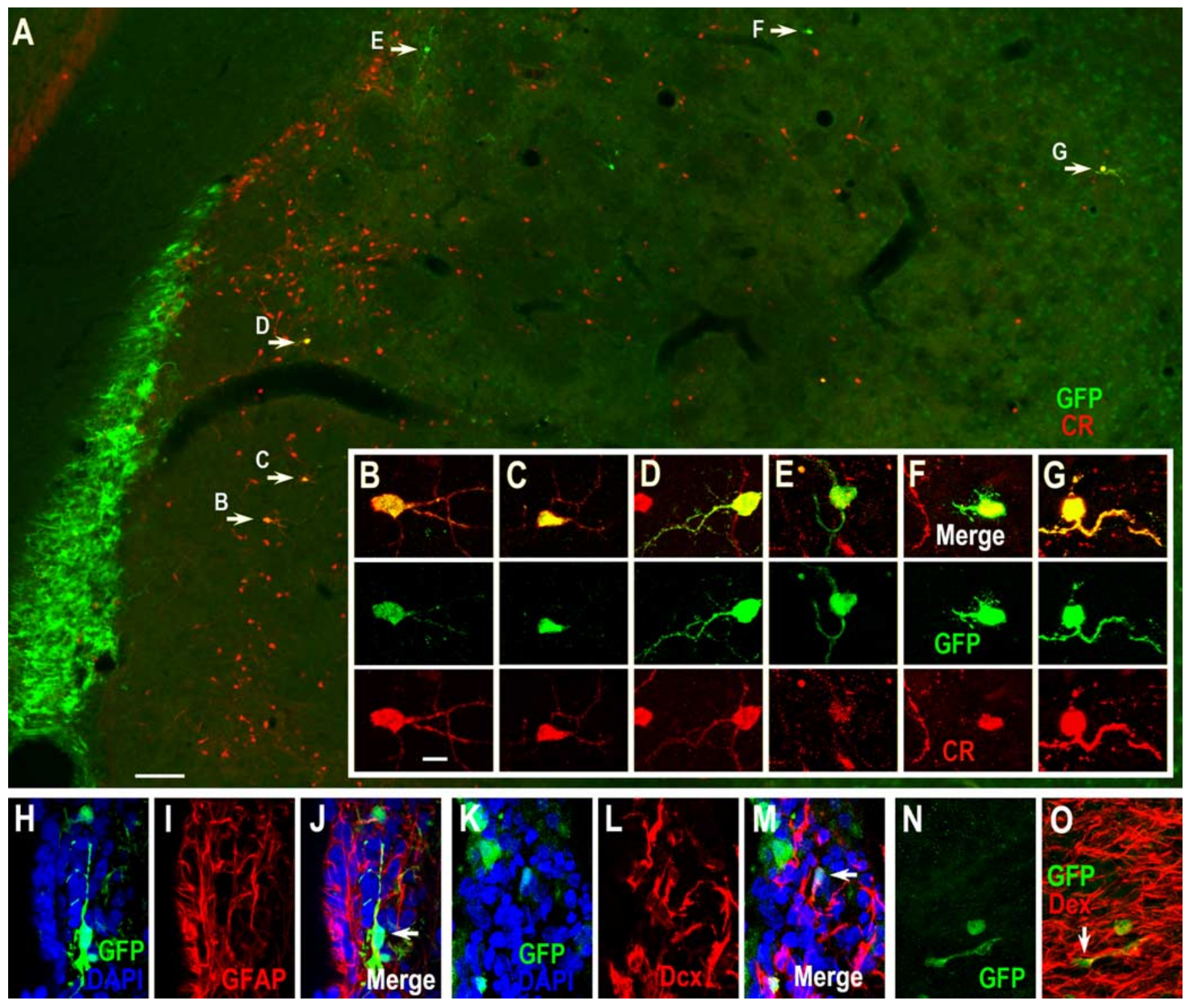

Figure 5. Lentivirus-labeled SVZ-derived cells in the damaged striatum 6 weeks after stroke express CR. A, Self-inactivating lentiviruses expressing GFP were injected into the SVZ $1 \mathrm{~d}$ before inducing stroke and GFP/CR double immunostaining was performed 6 weeks after stroke showing that most GFP-labeled cells in the damaged striatum express (R. $\boldsymbol{B}$-G, Higher magnification of $\mathrm{GFP}^{+} / \mathrm{CR}^{+}$cells in $\boldsymbol{A}$ (arrows). Note that one GFP ${ }^{+}$cell in $\boldsymbol{E}$ lightly expresses (R protein. $\boldsymbol{H}-\boldsymbol{J}$, Photomicrographs of A GFP ${ }^{+} / \mathrm{GFAP}^{+}$cell (arrow in $\boldsymbol{J}$ ) in the SVZ 6 weeks after stroke. $\boldsymbol{K}-\mathbf{0}$, Photomicrographs of GFP ${ }^{+} / D_{C x}{ }^{+}$cells in the SVZ (arrow in $\boldsymbol{M}$ ) and RMS (arrow in $\mathbf{0}$ ) 6 weeks after stroke. Scale bars: $\boldsymbol{A}, 100 \mu \mathrm{m}$; (in $\boldsymbol{B}$ ) $\boldsymbol{B}-\mathbf{0}, 10 \mu \mathrm{m}$.

tered or scattered and displayed different morphologies; most were small striatal interneuron-like cells (Fig. $7 B, D, E$ ). Compared with the density of $\mathrm{BrdU}^{+} / \mathrm{CR}^{+}$cells at 6 weeks poststroke, only a very low density of $\mathrm{BrdU}^{+} / \mathrm{CR}^{+}$cells were found in the damaged striatum 6 months after stroke ( 23 vs 3 cells $/ 0.144 \mathrm{~mm}^{3}$ respectively), suggesting that newborn $\mathrm{CR}^{+}$cells are gradually eliminated in the damaged striatum. Quantitative analysis revealed that the number of $\mathrm{CR}^{+}$cells in the ipsilateral striatum was significantly higher than that in the contralateral striatum ( $405 \pm 53.6$ vs $815 \pm 196.4$ cells in contralateral vs ipsilateral striatum; $p=0.04$ by Student's $t$ test, $n=5$ rats), although loss of ipsilateral striatal volume occurred due to the ischemic injury. This result further supports the conclusion that virtually only $\mathrm{CR}^{+}$cells are generated in the damaged striatum after stroke.

The vast majority of newborn neurons in the damaged striatum express the transcription factor Sp8

The above results do not exclude the possibility that some projection neurons or other types of striatal interneurons are gener- ated after stroke. For instance, such cells may be generated, but are not fully differentiated and/or die in the damaged striatum. The transcription factors COUP TF1-interacting protein 2 (Ctip2) and forkhead box P1 (Foxp1) are expressed by young and mature striatal medium-sized spiny projection neurons but not striatal interneurons (Tamura et al., 2004; Arlotta et al., 2008). The LIM-homeobox factor Islet1 is expressed by striatal cholinergic interneurons (Elshatory and Gan, 2008). Indeed, during development, many $\mathrm{Dcx}^{+}$cells in the lateral ganglionic eminence (striatal primordium) express Ctip2, Foxp1 and Islet1 (supplemental Fig. 2, available at www.jneurosci.org as supplemental material) (Arlotta et al., 2008). However, none of these transcription factors were detected in $\mathrm{Dcx}^{+}$cells in the stroke-damaged striatum of adult rats (supplemental Fig. 2, available at www. jneurosci.org as supplemental material).

Previous studies have shown that $S p 8$, a new member of the Sp1 zinc finger transcription factor linked to survival, migration and correct specification of a large proportion of OB interneurons, is expressed by most neuroblasts, but not by transit- 


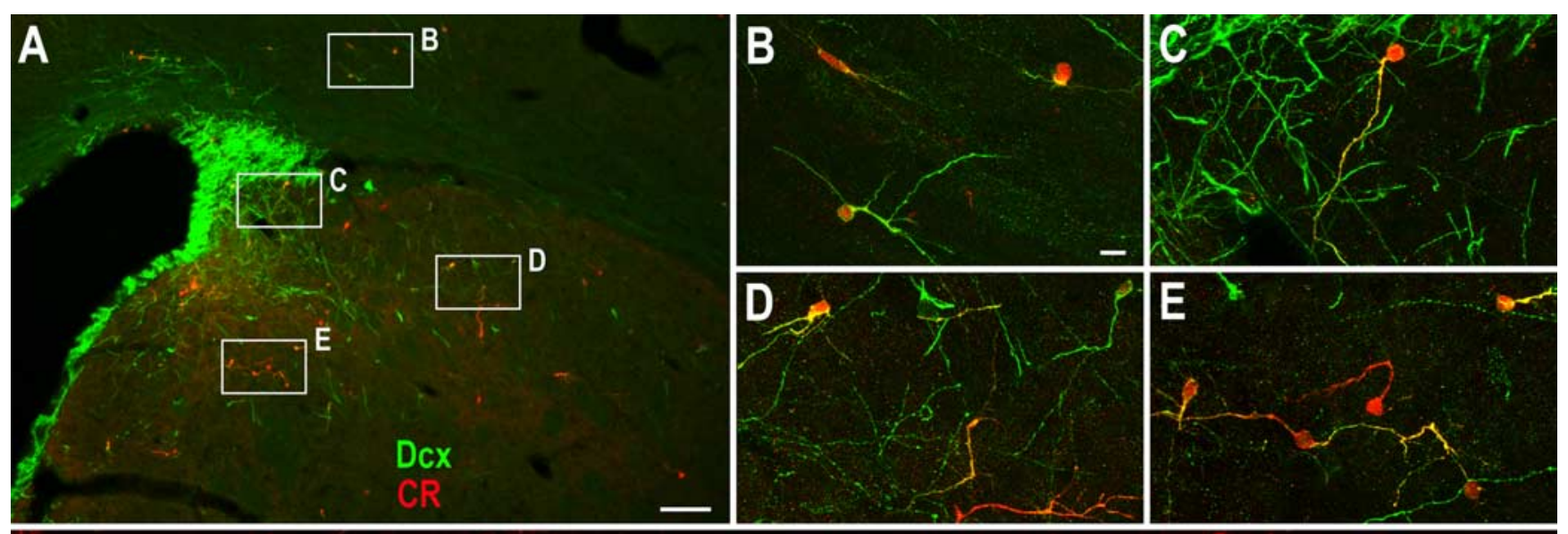

$\mathbf{F}$

CR

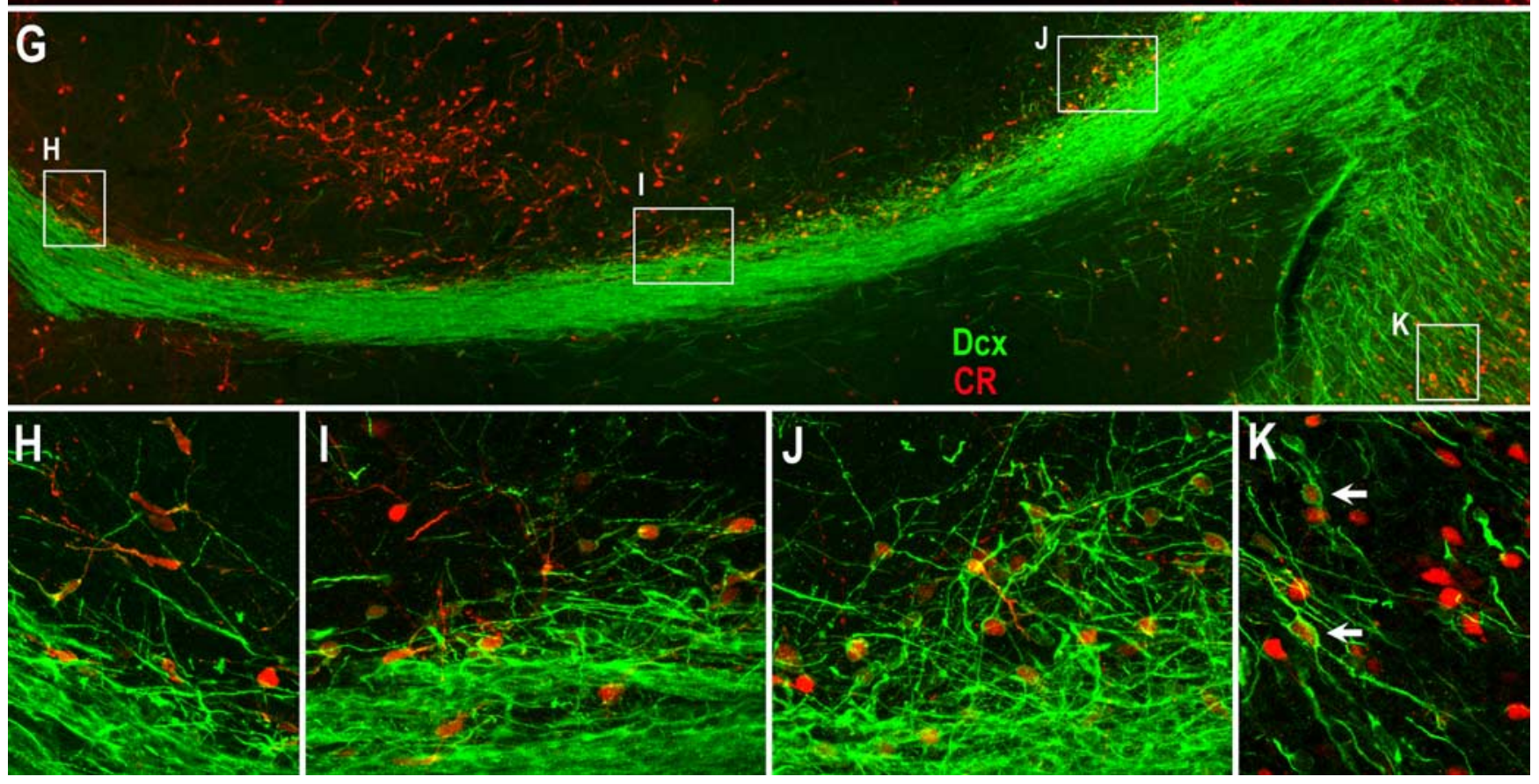

Figure 6. Newly born young neurons in the damaged striatum express CR. $A, D c x / C R$ double immunostaining in the damaged striatum 2 weeks after stroke. $\boldsymbol{B}-\boldsymbol{E}$, Higher magnification of the boxed areas in $\boldsymbol{A}$ showing $D c x^{+} / C R^{+}$cells in the corpus callosum $(\boldsymbol{B})$ and damaged striatum $(\boldsymbol{C}-\boldsymbol{E})$. $\boldsymbol{F}, \boldsymbol{G}$, Photomicrographs of $C R(\boldsymbol{F})$ and $D c x / C R$ double $(\boldsymbol{G})$ immunostaining in the RMS and $0 B$ of the normal adult rat brain (10 weeks old). $\boldsymbol{H}-\boldsymbol{K}$, Higher magnification of the boxed areas in $\boldsymbol{G}$ showing $D c{ }^{+} / \mathrm{CR}^{+}$cells in the RMS and its surroundings $(\boldsymbol{H}-\boldsymbol{J})$ and the $0 \mathrm{~B}(\boldsymbol{K}$, arrows). Scale bars: (in A) $\boldsymbol{A}, \boldsymbol{F}, \mathbf{G}, 100 \mu \mathrm{m}$; (in $\boldsymbol{B}) \boldsymbol{B}-\boldsymbol{E}, \boldsymbol{H}-\boldsymbol{K}, 10 \mu \mathrm{m}$.

amplifying progenitor cells in the mouse SVZ and RMS (Waclaw et al., 2006). Sp8 continues to be expressed by fully differentiated interneurons of the mouse OB (Waclaw et al., 2006). Therefore, we first evaluated Sp8 expression in neuroblasts of the adult rat SVZ. By double immunostaining for Dcx and Sp8, we found that $>96 \%$ of neuroblasts in the SVZ along the entire lateral wall of the ventricle expressed Sp8 (Fig. $8 A-D ; 1800$ of $1856, n=3$ rats).
This suggests that the majority of neuroblasts of the adult rat SVZ are homogeneous in terms of Sp8 expression. Similarly, the vast majority of the neuroblasts in the rat RMS also expressed Sp8 (supplemental Fig. 3, available at www.jneurosci.org as supplemental material) (Waclaw et al., 2006).

Surprisingly, we found that the vast majority of $\mathrm{Dcx}^{+}$cells in the damaged striatum expressed Sp8 2 weeks after stroke (Fig. 8 F; 


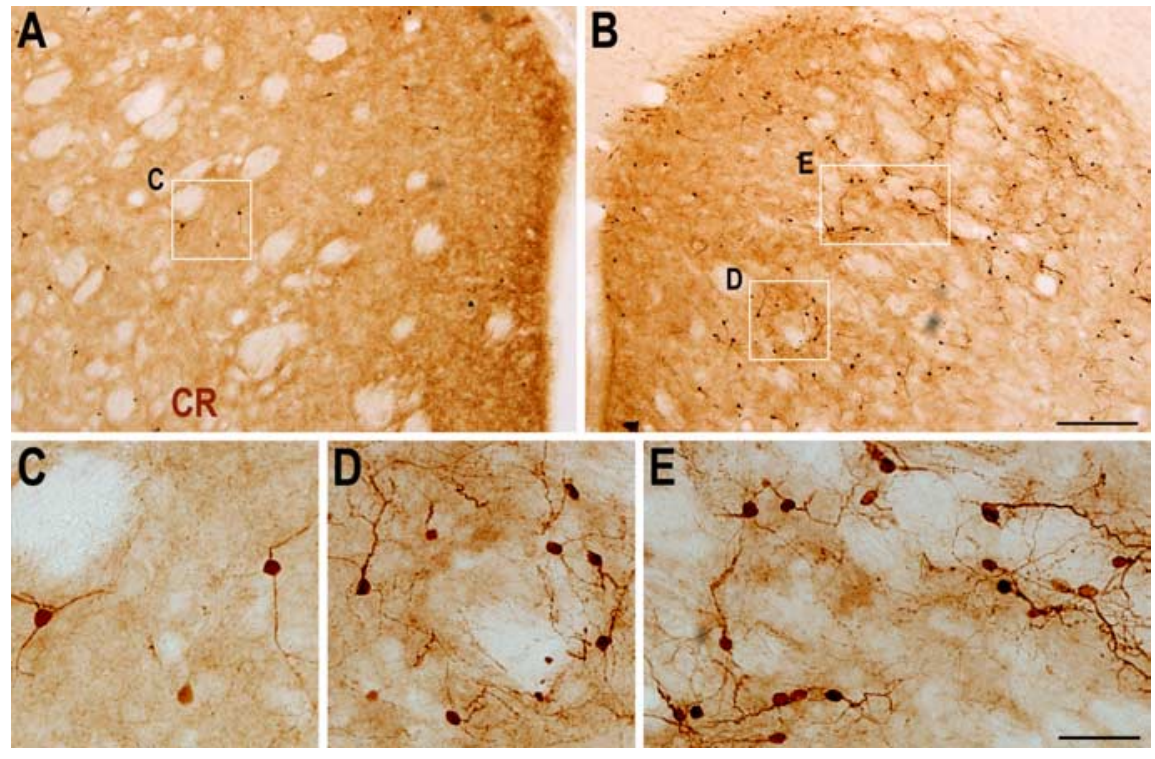

Figure 7. $C \mathrm{CR}^{+}$cells are more abundant in the ipsilateral striatum 6 months after stroke, compared with the contralateral striatum. $\boldsymbol{A}, \boldsymbol{B}$, Photomicrographs of $C$ immunostaining in the contralateral $(\boldsymbol{A})$ and ipsilateral $(\boldsymbol{B})$ striatum 6 months after stroke. $\boldsymbol{C}$, Higher magnification of the boxed area in $(\boldsymbol{A}) . \boldsymbol{D}, \boldsymbol{E}$, Higher magnification of the boxed areas in $\boldsymbol{B}$ showing morphology of $C R^{+}$ cells in the damaged striatum. Scale bars: (in $\boldsymbol{B}) \boldsymbol{A}, \boldsymbol{B}, 200 \mu \mathrm{m}$; (in $\boldsymbol{E}) \boldsymbol{C}-\boldsymbol{E}, 50 \mu \mathrm{m}$.

supplemental Fig. 4, available at www.jneurosci.org as supplemental material; 745 of $757, n=2$ rats). Moreover, all of the $\mathrm{CR}^{+} / \mathrm{Sp} 8{ }^{+}$cells had diameters corresponding to small interneurons $(7.51 \pm 0.11 \mu \mathrm{m}$; mean $\pm \mathrm{SEM}$, the longest axis $)$, whereas all of the $\mathrm{CR}^{+} / \mathrm{Sp} 8^{-}$cells had features of medium-sized aspiny interneurons $(11.4 \pm 0.13 \mu \mathrm{m})$ in the normal and damaged striatum (Fig. 8G,H). The ratio of $\mathrm{CR}^{+} / \mathrm{Sp} 8^{+}$cells vs $\mathrm{CR}^{+} / \mathrm{Sp} 8^{-}$cells is $0.7: 1$ in normal striatum whereas it is $2: 1$ in the damaged striatum 6 weeks after stroke. These results suggest that Sp8 is expressed by the vast majority of newly born neurons in the damaged striatum. This conclusion is reinforced by the observation that all $\mathrm{BrdU}^{+} / \mathrm{CR}^{+}$cells in the damaged striatum expressed Sp8 (Fig. $8 I-L ; 69$ cells counted). In the adult OB, among all newly generated neurons, the majority are granular cells; a small number of them are periglomerular cells and a very small number are external plexiform interneurons (Altman, 1969; Bayer, 1983; Lois and Alvarez-Buylla, 1994; Winner et al., 2002; Hack et al., 2005; Batista-Brito et al., 2008; Yang, 2008). Notably, many of the newly born granular cells, the majority of the newly born periglomerular cells and all of the newly born external plexiform interneurons express CR (Winner et al., 2002; Batista-Brito et al., 2008; Yang, 2008). It is exactly these groups of interneurons expressing $\mathrm{Sp} 8$ in the $\mathrm{OB}$ because the majority of $\mathrm{Dcx}^{+}$young neurons (Fig. 9) and nearly all $\mathrm{CR}^{+}$mature interneurons in the granular cell layer, external plexiform layer and glomerular layer of the OB express Sp8 (supplemental Fig. 5, available at www. jneurosci.org as supplemental material) (Waclaw et al., 2006). Collectively, our results show that, after stroke occurs, a subset of the SVZ neuroblasts that normally migrate anteriorly into the adult $\mathrm{OB}$ via the RMS turn a corner and migrate into the damaged striatum, where they eventually differentiate into $\mathrm{CR}^{+}$ interneuron-like cells. During this process, neuroblasts in the SVZ, newly born young and mature neurons in the damaged striatum constitutively express the transcription factor Sp8, suggesting that the vast majority of neurons produced in the damaged striatum after stroke remain intrinsically specified to produce a single lineage of interneurons (Fig. 10).

\section{Discussion}

It is well established that the slowly dividing SVZ neural stem cells (type B cells) generate rapidly dividing transit amplifying progenitors (type $\mathrm{C}$ cells), which in turn generate neuroblasts (type A cells) that migrate forwards along the RMS into the $\mathrm{OB}$, where they give rise to olfactory interneurons throughout life (Doetsch et al., 1999; Mirzadeh et al., 2008). Brain injury, such as stroke, results in the death of large numbers of both projection neurons and inhibitory interneurons in the damaged striatum. Previous studies have suggested that newly born neurons generated from the adult SVZ progenitor cells can differentiate into neurons with regionappropriate phenotypes within damaged areas after stroke or other brain injuries (Magavi et al., 2000; Arvidsson et al., 2002; Nakatomi et al., 2002; Parent et al., 2002; Teramoto et al., 2003; Collin et al., 2005). In particular, studies have suggested that the neuroblasts of the SVZ produce medium-sized spiny neurons after stroke (Arvidsson et al., 2002; Parent et al., 2002). Our findings show that although robust production of new neurons in the damaged striatum from the adjacent SVZ occurs after stroke, these newborn neurons are restricted to a single subtype: $\mathrm{CR}^{+}$small interneuron-like cells, resulting in the accumulation of these cells in the damaged striatum at long recovery times after stroke. Because $\mathrm{CR}^{+} / \mathrm{Sp} 8^{+}$cells are the major population of $\mathrm{OB}$ interneurons that are constantly produced in the SVZ of the normal adult brain, we propose that newly born $\mathrm{CR}^{+}$interneuronlike cells in the damaged striatum after stroke are mostly misdirected $\mathrm{OB}$ neurons. However, we did not examine disruption of integrity of the glial tubes in the SVZ and RMS by electron microscopy as a possible reason for the misdirected migration of $\mathrm{OB}$ interneurons into the damaged striatum after stroke. It is also important to point out that even in undamaged adult rat brain, a very small number of neuroblasts $\left(\mathrm{Dcx}^{+}\right.$cells), which appear to migrate from the SVZ into the striatum, differentiate into $\mathrm{CR}^{+}$ interneurons (Dayer et al., 2005). These $\mathrm{Dcx}^{+}$cells also express Sp8 (Fig. 8E), so it is possible that these newly born $\mathrm{CR}^{+} / \mathrm{Sp} 8^{+}$ cells are indeed "striatal interneurons" that are produced only at an extremely low frequency in the intact brain, but markedly augmented after striatal damage. But in either case, the transcription factor Sp8 is expressed constitutively during this entire process. Therefore, we conclude that the intrinsic differentiation potential of adult SVZ neuroblasts is not altered after brain injury (Fig. 10).

Adult somatic (tissue-specific) stem cells are defined as clonogenic, self-renewing progenitor cells that can generate one or more specialized cell types. The developmental plasticity of these cells has potentially important theoretical implications. However, although this definition accurately describes the behavior of adult hematopoietic stem cells both in vivo and in vitro (Morrison et al., 1995), it does not necessarily reflect the behavior of adult neural stem cells in vivo (Merkle and Alvarez-Buylla, 2006). In the culture dish, neural stem cells both in the hippocampal dentate gyrus and SVZ can be passaged and differentiated into astrocytes, neurons, and oligodendrocytes (Doetsch et al., 1999; Suh et al., 

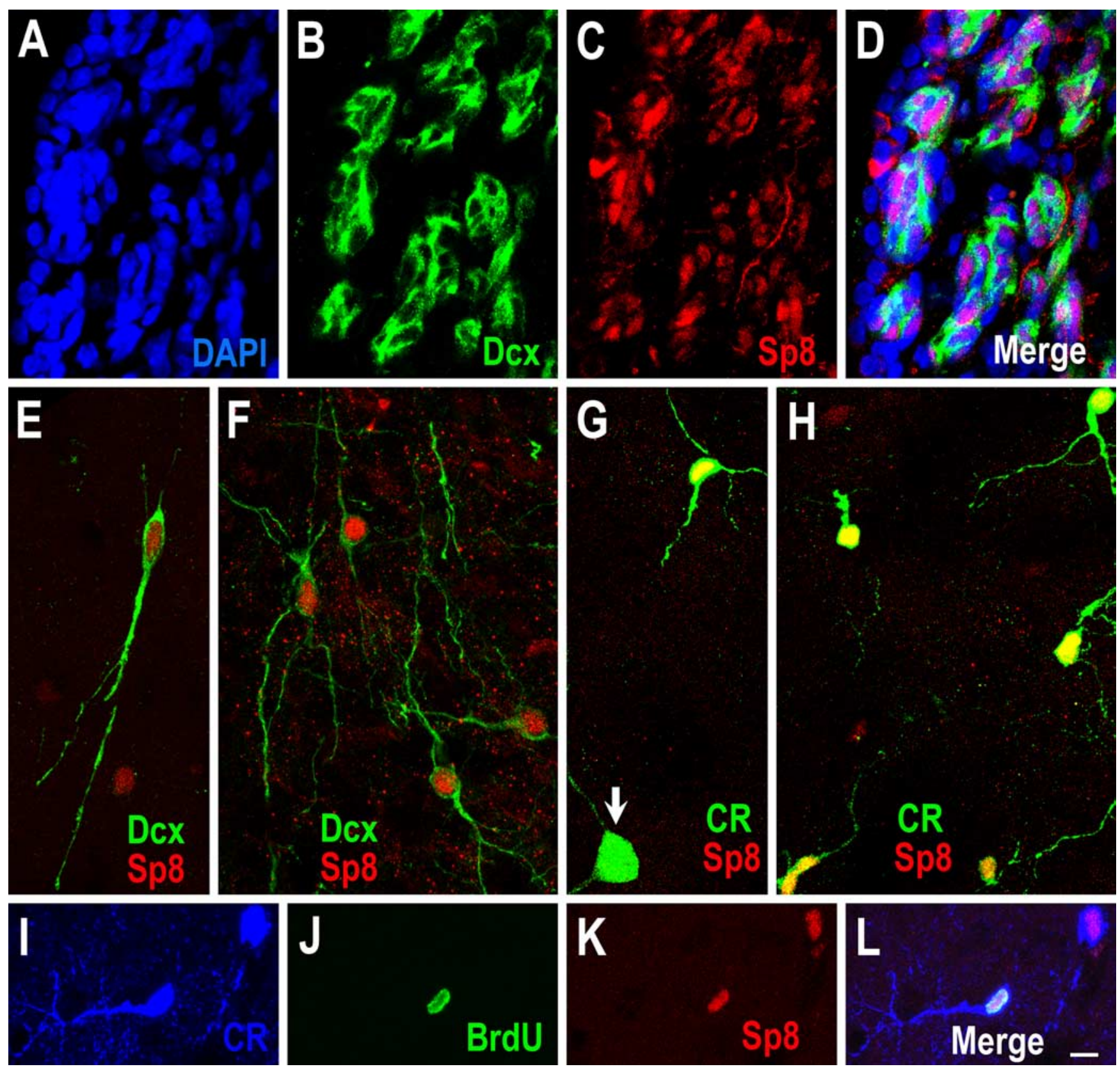

Figure 8. Newly born neurons in the damaged striatum express Sp8. $\boldsymbol{A}-\boldsymbol{D}, D c x^{+}$cells in the adult rat SVZ express Sp8. $\boldsymbol{E}, \boldsymbol{F}, D \mathrm{Dx}^{+}$cells in the normal $(\boldsymbol{E})$ and damaged $(\boldsymbol{F})$ striatum express Sp8. $\mathbf{G}, \boldsymbol{H}, \mathrm{CR}^{+} / \mathrm{Sp} 8{ }^{+}$cells are small interneuron-like cells in the normal $(\boldsymbol{G})$ and damaged $(\boldsymbol{H})$ striatum. Note that a $\mathrm{CR}^{+}$medium-sized aspiny neuron does not express $\mathrm{Sp8}$ (arrow in $\mathbf{G}$ ). $\boldsymbol{I}-\boldsymbol{L}$, Photomicrographs of a BrdU ${ }^{+} / \mathrm{CR}^{+} / \mathrm{Sp8} 8^{+}$cell in the damaged striatum 6 weeks after stroke. Scale bar: (in $\left.\boldsymbol{L}\right) \boldsymbol{A}-\boldsymbol{L}, 10 \mu \mathrm{m}$.

2007; Mirzadeh et al., 2008). In the adult brain, neural stem cells can produce both neurons and glial cells (Ahn and Joyner, 2005; Menn et al., 2006; Suh et al., 2007) and retain substantial developmental "plasticity," as demonstrated by the ability to switch from neuronal to glial fates when exposed to a new source of positional information (Hack et al., 2005; Jackson et al., 2006; Colak et al., 2008; Jessberger et al., 2008). This developmental plasticity is not unlimited, however, since neural stem cells seem to be restricted with respect to the types of neuroblasts they can generate and these neuroblasts are not susceptible to being respecified (Merkle et al., 2007). Moreover, we do not know whether individual neural stem cells have the potential to give rise to both neurons and glial cells in the adult brain.

Reduced plasticity in adult neuroblasts may be due to the expression of specific transcription factors. Indeed, two tran- scription factors, Pax6 and Sp8, have been identified in migrating neuroblasts and continue to be expressed in differentiated OB interneurons (Hack et al., 2005; Kohwi et al., 2005; Waclaw et al., 2006). Although we found that there are some $\mathrm{Pax} 6^{+} / \mathrm{Sp} 8^{+}$cells in the SVZ-RMS-OB system, we did not find any Dcx ${ }^{+} / \mathrm{Pax}^{+}$ cell in the damaged striatum in our experiments (data not shown). This raises the possibility that only $\mathrm{CR}^{+} / \mathrm{Sp} 8^{+}$committed neuroblasts have the ability to migrate out the SVZ and into the damaged striatum after stroke. In line with this interpretation, previous studies have shown that olfactory bulbectomy does not stop the production of neuroblasts in the SVZ, nor their migration, but these neuroblasts are more likely to differentiate into $\mathrm{CR}^{+}$neurons and to integrate into neighboring brain parenchyma (Jankovski et al., 1998; Kirschenbaum et al., 1999).

It has been reported that subsequent to ischemic injury in the 

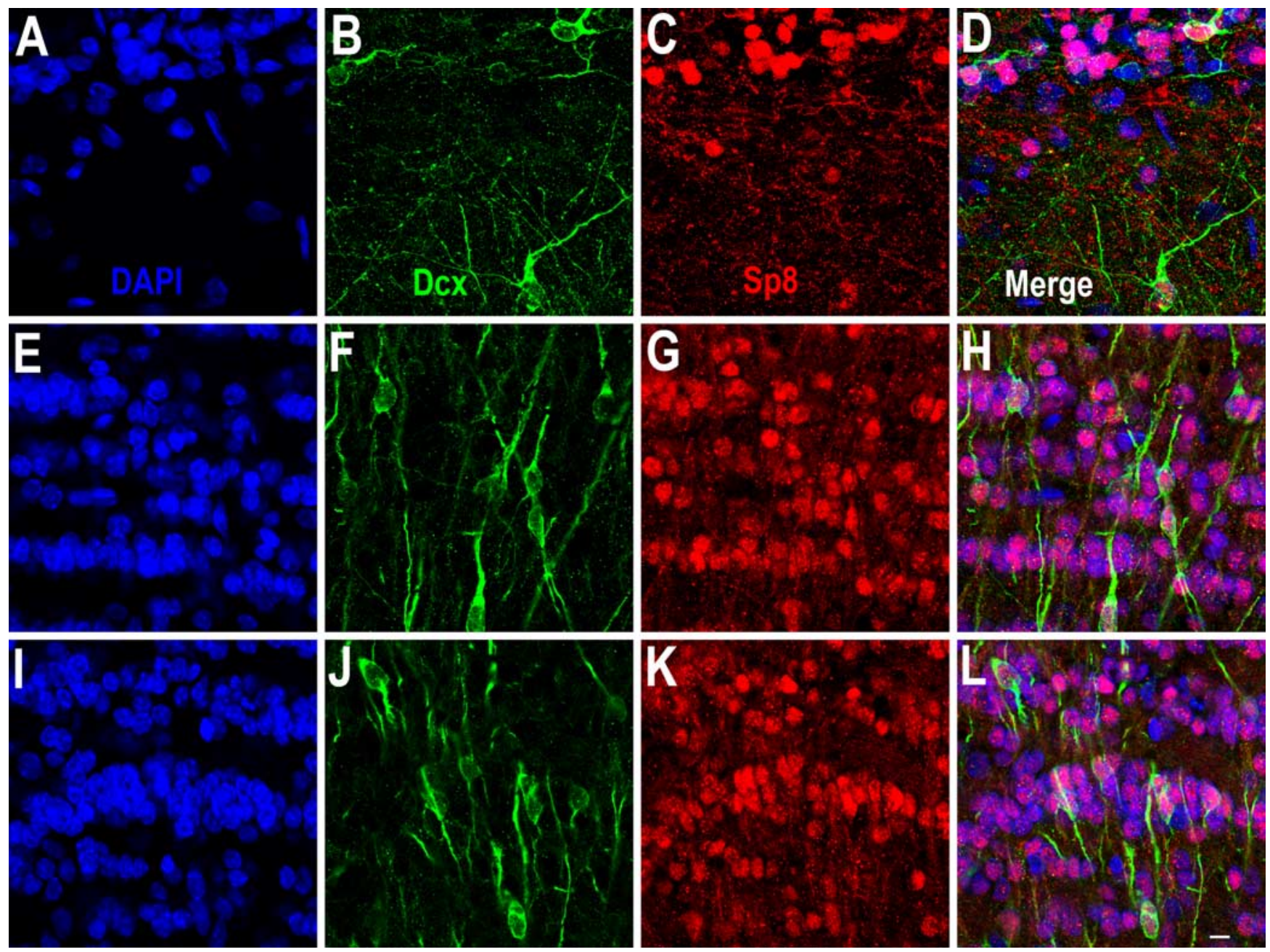

Figure 9. The majority of $\mathrm{Dcx}{ }^{+}$cells in the adult $0 B$ express Sp8. $\boldsymbol{A}-\boldsymbol{L}$, Photomicrographs of $\mathrm{Dcx}{ }^{+} / \mathrm{Sp} 8^{+}$cells in the glomerular layer and external plexiform layer $(\boldsymbol{A}-\boldsymbol{D})$, superficial $(\boldsymbol{E}-\boldsymbol{H})$ and deep $(\boldsymbol{I}-\boldsymbol{L})$ granular cell layer of the $0 \mathrm{~B}$. Scale bar: (in $\boldsymbol{L}) \boldsymbol{A}-\boldsymbol{L}, 10 \mu \mathrm{m}$.

adult rat, the newly generated neurons are predominantly medium-sized spiny projection neurons (Arvidsson et al., 2002; Parent et al., 2002). Both studies have clearly shown that SVZ progenitor cell proliferation plays a major role in neurogenesis in the damaged striatum after stroke. To investigate the type of newly born neurons after adult stroke, both studies used DARPP-32 as a marker for medium-sized spiny neurons. One study, however, found that DARPP-32 was expressed in the SVZRMS-OB system of both the damaged (ipsilateral) and undamaged (contralateral) hemispheres. They suggested that newly formed neurons may transiently express DARPP-32 after stroke (Parent et al., 2002). This provides a possible reinterpretation of their results, but this remains to be clearly demonstrated. Another study used expression of the transcription factors Pbx and Meis 2 to mark developing striatal medium-sized spiny projection neurons (Arvidsson et al., 2002). However, many interneurons in the adult $\mathrm{OB}$, including a subset of $\mathrm{CR}^{+}$cells express these two factors (supplemental Fig. 6A-C, available at www.jneurosci.org as supplemental material) (Redmond et al., 1996; Allen et al., 2007). Moreover, we found that some $\mathrm{CR}^{+}$cells in the normal striatum and some newly born $\mathrm{CR}^{+}$cells in the damaged striatum after stroke express Pbx as well (supplemental Fig. 6D-G, available at www.jneurosci.org as supplemental material). Thus, although virtually all $\mathrm{Dcx}^{+}$cells express Pbx and Meis2 in the damaged striatum after ischemic stroke (Arvidsson et al., 2002), these two factors could not be used as specific markers for young or mature medium-sized spiny projection neurons in the striatum.

Because the vast majority of $\mathrm{Dcx}^{+}$cells in the damaged striatum that were generated from the SVZ express Sp8 and these cells eventually differentiate into $\mathrm{CR}^{+}$interneurons, our results indicate that the transcription factor Sp8 and the calcium-binding protein CR can be used as markers for neurogenesis in the SVZRMS-OB system in normal and damaged brains. Merkle et al. (2007) reported that $\mathrm{CR}^{+}$granular cells and periglomerular cells of the OB are produced in the medial wall of the anterior SVZ. A small number of $\mathrm{OB} \mathrm{CR}{ }^{+}$cells are also produced in dorsal SVZ, but very few $\mathrm{CR}^{+}$cells are derived from the lateral wall of the SVZ (Merkle et al., 2007). Interestingly, we found that many Dcx ${ }^{+}$ cells and $\mathrm{Dcx}^{+} / \mathrm{CR}^{+}$cells were located very close to the dorsolateral SVZ (Fig. 6C). Because tangentially migrating neuroblasts distribute along the length of the lateral ventricle wall and traverse a complex network of interconnected paths before joining the RMS (Doetsch and Alvarez-Buylla, 1996), it is possible that newly born $\mathrm{CR}^{+}$cells in the damaged striatum are derived from the neural stem cells that reside in different regions, such as medial or dorsal part of the SVZ. Nevertheless, the locations of neural stem cells in the SVZ that give rise to $\mathrm{CR}^{+}$cells in the damaged striatum after stroke remain to be clearly determined.

It would be interesting to know the function of newly born 
$\mathrm{CR}^{+}$inhibitory interneurons in the damaged striatum. Because $\mathrm{CR}^{+}$interneurons represent only $0.5 \%$ of all striatal neurons in the adult rat brain (Rymar et al., 2004), our data collectively suggest that the regenerative capacity of the neural progenitor cells and their descendants (neuroblasts) in the SVZ after stroke is limited. Although we cannot exclude the existence of very rare newborn neurons other than $\mathrm{CR}^{+}$cells that escaped detection because not all $\mathrm{Dcx}^{+}$cells expressed Sp8 in the damaged striatum after stroke in our experiments (supplemental Fig. 4, available at www.jneurosci.org as supplemental material), or the possibility that we still missed to label a few slowly dividing neural stem cells that might have contributed to production of DARPP $-32^{+}$projection neurons in the damaged striatum because we used periodic intraperitoneal injections of BrdU, not continuous supply through drinking BrdU-containing water, it is unlikely that these rare cells significantly contribute to functional recovery of striatal circuits.

The fact that neural progenitor cells are not readily respecified in the embryonic cortex (Shen et al., 2006), spinal cord (Mukouyama et al., 2006), postnatal SVZ (Merkle et al., 2007) and damaged brain (this study), suggests that the strategies for brain repair that are based only on increasing adult neurogenesis need to be reevaluated. It is likely that epigenetic reprogramming of the dividing neural stem cells in the adult SVZ will be required for the development of successful cell-based therapies for repairing a damaged brain.

\section{References}

Ahn S, Joyner AL (2005) In vivo analysis of quiescent adult neural stem cells responding to sonic hedgehog. Nature 437:894-897.

Allen ZJ 2nd, Waclaw RR, Colbert MC, Campbell K (2007) Molecular identity of olfactory bulb interneurons: transcriptional codes of periglomerular neuron subtypes. J Mol Histol 38:517-525.

Altman J (1969) Autoradiographic and histological studies of postnatal neurogenesis. IV. Cell proliferation and migration in the anterior forebrain, with special reference to persisting neurogenesis in the olfactory bulb. J Comp Neurol 137:433-457.

Alvarez-Buylla A, Lim DA (2004) For the long run: maintaining germinal niches in the adult brain. Neuron 41:683-686.

Arlotta P, Molyneaux BJ, Jabaudon D, Yoshida Y, Macklis JD (2008) Ctip2 controls the differentiation of medium spiny neurons and the establishment of the cellular architecture of the striatum. J Neurosci 28:622-632.

Arvidsson A, Collin T, Kirik D, Kokaia Z, Lindvall O (2002) Neuronal replacement from endogenous precursors in the adult brain after stroke. Nat Med 8:963-970.

Batista-Brito R, Close J, Machold R, Fishell G (2008) The distinct temporal origins of olfactory bulb interneuron subtypes. J Neurosci 28:3966-3975.

Bayer SA (1983) 3H-thymidine-radiographic studies of neurogenesis in the rat olfactory bulb. Exp Brain Res 50:329-340.

Colak D, Mori T, Brill MS, Pfeifer A, Falk S, Deng C, Monteiro R, Mummery C, Sommer L, Götz M (2008) Adult neurogenesis requires Smad4mediated bone morphogenic protein signaling in stem cells. J Neurosci 28:434-446.
Collin T, Arvidsson A, Kokaia Z, Lindvall O (2005) Quantitative analysis of the generation of different striatal neuronal subtypes in the adult brain following excitotoxic injury. Exp Neurol 195:71-80.

Dayer AG, Cleaver KM, Abouantoun T, Cameron HA (2005) New GABAergic interneurons in the adult neocortex and striatum are generated from different precursors. J Cell Biol 168:415-427.

Doetsch F, Alvarez-Buylla A (1996) Network of tangential pathways for neuronal migration in adult mammalian brain. Proc Natl Acad Sci U S A 93:14895-14900.

Doetsch F, Caillé I, Lim DA, García-Verdugo JM, Alvarez-Buylla A (1999) Subventricular zone astrocytes are neural stem cells in the adult mammalian brain. Cell 97:703-716.

Elshatory Y, Gan L (2008) The LIM-homeobox gene Islet-1 is required for the development of restricted forebrain cholinergic neurons. J Neurosci 28:3291-3297.

Geraerts M, Eggermont K, Hernandez-Acosta P, Garcia-Verdugo JM, Baekelandt V, Debyser Z (2006) Lentiviral vectors mediate efficient and stable gene transfer in adult neural stem cells in vivo. Hum Gene Ther 17:635-650.

Hack MA, Saghatelyan A, de Chevigny A, Pfeifer A, Ashery-Padan R, Lledo PM, Götz M (2005) Neuronal fate determinants of adult olfactory bulb neurogenesis. Nat Neurosci 8:865-872.

Jackson EL, Garcia-Verdugo JM, Gil-Perotin S, Roy M, Quinones-Hinojosa A, VandenBerg S, Alvarez-Buylla A (2006) PDGFR alpha-positive B cells are neural stem cells in the adult SVZ that form glioma-like growths in response to increased PDGF signaling. Neuron 51:187-199. 
Jankovski A, Garcia C, Soriano E, Sotelo C (1998) Proliferation, migration and differentiation of neuronal progenitor cells in the adult mouse subventricular zone surgically separated from its olfactory bulb. Eur J Neurosci 10:3853-3868.

Jessberger S, Toni N, Clemenson GD Jr, Ray J, Gage FH (2008) Directed differentiation of hippocampal stem/progenitor cells in the adult brain. Nat Neurosci 11:888-893.

Jin K, Sun Y, Xie L, Peel A, Mao XO, Batteur S, Greenberg DA (2003) Directed migration of neuronal precursors into the ischemic cerebral cortex and striatum. Mol Cell Neurosci 24:171-189.

Kawaguchi Y, Wilson CJ, Augood SJ, Emson PC (1995) Striatal interneurones: chemical, physiological and morphological characterization. Trends Neurosci 18:527-535.

Kirschenbaum B, Doetsch F, Lois C, Alvarez-Buylla A (1999) Adult subventricular zone neuronal precursors continue to proliferate and migrate in the absence of the olfactory bulb. J Neurosci 19:2171-2180.

Kohwi M, Osumi N, Rubenstein JL, Alvarez-Buylla A (2005) Pax6 is required for making specific subpopulations of granule and periglomerular neurons in the olfactory bulb. J Neurosci 25:6997-7003.

Koizumi J, Yoshida Y, Nakazawa T, Ooneda G (1986) Experimental studies of ischemic brain edema. 1. A new experimental model of cerebral embolism in rats in which recirculation can be introduced in the ischemic area. Jpn J Stroke 8:1-8.

Kokaia Z, Thored P, Arvidsson A, Lindvall O (2006) Regulation of strokeinduced neurogenesis in adult brain-recent scientific progress. Cereb Cortex [Suppl 1]:i162-i167.

Levison SW, Goldman JE (1993) Both oligodendrocytes and astrocytes develop from progenitors in the subventricular zone of postnatal rat forebrain. Neuron 10:201-212.

Liu FC, Graybiel AM (1992) Heterogeneous development of calbindinD28K expression in the striatal matrix. J Comp Neurol 320:304-322.

Lois C, Alvarez-Buylla A (1994) Long-distance neuronal migration in the adult mammalian brain. Science 264:1145-1148.

Longa EZ, Weinstein PR, Carlson S, Cummins R (1989) Reversible middle cerebral artery occlusion without craniectomy in rats. Stroke 20:84-91.

Magavi SS, Leavitt BR, Macklis JD (2000) Induction of neurogenesis in the neocortex of adult mice. Nature 405:951-955.

Marin O, Anderson SA, Rubenstein JL (2000) Origin and molecular specification of striatal interneurons. J Neurosci 20:6063-6076.

Menn B, Garcia-Verdugo JM, Yaschine C, Gonzalez-Perez O, Rowitch D, Alvarez-Buylla A (2006) Origin of oligodendrocytes in the subventricular zone of the adult brain. J Neurosci 26:7907-7918.

Merkle FT, Alvarez-Buylla A (2006) Neural stem cells in mammalian development. Curr Opin Cell Biol 18:704-709.

Merkle FT, Mirzadeh Z, Alvarez-Buylla A (2007) Mosaic organization of neural stem cells in the adult brain. Science 317:381-384.

Ming GL, Song H (2005) Adult neurogenesis in the mammalian central nervous system. Annu Rev Neurosci 28:223-250.

Mirzadeh Z, Merkle FT, Soriano-Navarro M, Garcia-Verdugo JM, AlvarezBuylla A (2008) Neural stem cells confer unique pinwheel architecture to the ventricular surface in neurogenic regions of the adult brain. Cell Stem Cell 3:265-278.

Morrison SJ, Uchida N, Weissman IL (1995) The biology of hematopoietic stem cells. Annu Rev Cell Dev Biol 11:35-71.

Morshead CM, Reynolds BA, Craig CG, McBurney MW, Staines WA, Morassutti D, Weiss S, van der Kooy D (1994) Neural stem cells in the adult mammalian forebrain: a relatively quiescent subpopulation of subependymal cells. Neuron 13:1071-1082.

Mukouyama YS, Deneen B, Lukaszewicz A, Novitch BG, Wichterle H, Jessell TM, Anderson DJ (2006) Olig2 + neuroepithelial motoneuron progenitors are not multipotent stem cells in vivo. Proc Natl Acad Sci U S A 103:1551-1556.

Nakatomi H, Kuriu T, Okabe S, Yamamoto S, Hatano O, Kawahara N, Tamura A, Kirino T, Nakafuku M (2002) Regeneration of hippocampal pyramidal neurons after ischemic brain injury by recruitment of endog enous neural progenitors. Cell 110:429-441.

Ouimet CC, Langley-Gullion KC, Greengard P (1998) Quantitative immunocytochemistry of DARPP-32-expressing neurons in the rat caudatoputamen. Brain Res 808:8-12.

Parent JM, Vexler ZS, Gong C, Derugin N, Ferriero DM (2002) Rat forebrain neurogenesis and striatal neuron replacement after focal stroke. Ann Neurol 52:802-813.

Paxinos G, Watson C (1998) The rat brain in stereotaxic coordinates. New York: Academic.

Petreanu L, Alvarez-Buylla A (2002) Maturation and death of adult-born olfactory bulb granule neurons: role of olfaction. J Neurosci 22:6106-6113.

Redmond L, Hockfield S, Morabito MA (1996) The divergent homeobox gene PBX1 is expressed in the postnatal subventricular zone and interneurons of the olfactory bulb. J Neurosci 16:2972-2982.

Rymar VV, Sasseville R, Luk KC, Sadikot AF (2004) Neurogenesis and stereological morphometry of calretinin-immunoreactive GABAergic interneurons of the neostriatum. J Comp Neurol 469:325-339.

Shen Q, Wang Y, Dimos JT, Fasano CA, Phoenix TN, Lemischka IR, Ivanova NB, Stifani S, Morrisey EE, Temple S (2006) The timing of cortical neurogenesis is encoded within lineages of individual progenitor cells. Nat Neurosci 9:743-751.

Suh H, Consiglio A, Ray J, Sawai T, D’Amour KA, Gage FH (2007) In vivo fate analysis reveals the multipotent and self-renewal capacities of Sox2(+) neural stem cells in the adult hippocampus. Cell Stem Cell 1:515-528.

Tamura S, Morikawa Y, Iwanishi H, Hisaoka T, Senba E (2004) Foxp1 gene expression in projection neurons of the mouse striatum. Neuroscience 124:261-267.

Teramoto T, Qiu J, Plumier JC, Moskowitz MA (2003) EGF amplifies the replacement of parvalbumin-expressing striatal interneurons after ischemia. J Clin Invest 111:1125-1132.

Thored P, Arvidsson A, Cacci E, Ahlenius H, Kallur T, Darsalia V, Ekdahl CT, Kokaia Z, Lindvall O (2006) Persistent production of neurons from adult brain stem cells during recovery after stroke. Stem Cells 24:739-747.

Waclaw RR, Allen ZJ 2nd, Bell SM, Erdélyi F, Szabó G, Potter S, Campbell K (2006) The zinc finger transcription factor Sp8 regulates the generation and diversity of olfactory bulb interneurons. Neuron 49:503-516.

Wichterle H, Turnbull DH, Nery S, Fishell G, Alvarez-Buylla A (2001) In utero fate mapping reveals distinct migratory pathways and fates of neurons born in the mammalian basal forebrain. Development 128:3759-3771.

Winner B, Cooper-Kuhn CM, Aigner R, Winkler J, Kuhn HG (2002) Long term survival and cell death of newly generated neurons in the adult rat olfactory bulb. Eur J Neurosci 16:1681-1689.

Yamashita T, Ninomiya M, Hernández Acosta P, García-Verdugo JM, Sunabori T, Sakaguchi M, Adachi K, Kojima T, Hirota Y, Kawase T, Araki N, Abe K, Okano H, Sawamoto K (2006) Subventricular zone-derived neuroblasts migrate and differentiate into mature neurons in the post-stroke adult striatum. J Neurosci 26:6627-6636.

Yang Z (2008) Postnatal subventricular zone progenitors give rise not only to granular and periglomerular interneurons but also to interneurons in the external plexiform layer of the rat olfactory bulb. J Comp Neurol 506:347-358.

Yang Z, Levison SW (2007) Perinatal hypoxic/ischemic brain injury induces persistent production of striatal neurons from subventricular zone progenitors. Dev Neurosci 29:331-340.

Yang Z, You Y, Levison SW (2008) Neonatal hypoxic/ischemic brain injury induces production of calretinin-expressing interneurons in the striatum. J Comp Neurol 511:19-33.

Zhao C, Deng W, Gage FH (2008) Mechanisms and functional implications of adult neurogenesis. Cell 132:645-660. 